\title{
Late Holocene coastal hydrographic and climate changes in the eastern North Sea
}

\author{
Dierk Hebbeln, ${ }^{*}$ Karen-Luise Knudsen, ${ }^{2}$ Richard \\ Gyllencreutz, ${ }^{3}$ Peter Kristensen, ${ }^{2}$ Dorthe Klitgaard-Kristensen, ${ }^{4}$ \\ Jan Backman, ${ }^{3}$ Carolyn Scheurle, ${ }^{1}$ Hui Jiang, ${ }^{5}$ Isabelle Gil, ${ }^{6}$ \\ Morten Smelror, ${ }^{7}$ Phil D. Jones ${ }^{8,9}$ and Hans-Petter Sejrup ${ }^{9}$
}

$\left({ }^{1}\right.$ Geowissenschaften, Universität Bremen, 28359 Bremen, Germany; ${ }^{2}$ Department of Earth Sciences, University of Aarhus, 8000 Arhus C, Denmark; ${ }^{3}$ Department of Geology and Geochemistry, Stockholm University, 10691 Stockholm, Sweden; ${ }^{4}$ Norwegian Polar Institute, 9296 Tromsø, Norway; ${ }^{5}$ State Key Laboratory of Estuarine and Coastal Research, East China Normal University, 200062 Shanghai, P.R. China; ${ }^{6}$ Marine Geology Department, National Institute of Engineering, Technology and Innovation, 2721-866 Alfragide, Portugal; ${ }^{7}$ Geological Survey of Norway, 7491 Trondheim, Norway; ${ }^{8}$ Climatic Research Unit, University of East Anglia, Norwich NR4 7TJ, UK; ${ }^{9}$ Department of Earth Sciences, University of Bergen, 5007 Bergen, Norway)

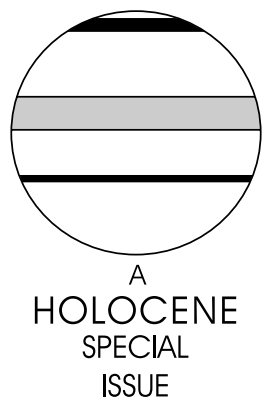

ISSUE

\begin{abstract}
We present a high-resolution palaeoenvironmental reconstruction covering the late Holocene from the Skagerrak and other sites in the North Sea area. The data, which are based on the analyses of marine sediment cores, reveal a marked environmental shift that took place between AD 700 and AD 1100 , with the most pronounced changes occurring at AD 900. Both surface and bottom waters in the Skagerrak were subject to major circulation and productivity changes at this time due to an enhanced advection of Atlantic waters to the North Sea marking the beginning of the 'Mediaeval Warm Period' (MWP). The observed increase in bottom current strength is especially remarkable as there is hardly any comparable signal in the older part of the record going back to $1000 \mathrm{BC}$. At the transition to the 'Little Ice Age' (LIA) the bottom current strength remains at a high level, now probably forced by atmospheric circulation. Thus, despite opposite temperature forcing, these two consecutive climate scenarios are apparently able to generate distinctly stronger bottom currents in the Skagerrak than observed in the preceding 2000 years, and demonstrate the significance of climatic forcing in shaping the marine environment. Indeed, both the MWP and the LIA are reported as strong climatic signals in northwest Europe, being the warmest (except the late twentieth century) and coldest periods, respectively, during at least the last 2000 years.
\end{abstract}

Key words: Late Holocene, climate variability, palaeoceanography, hydrographic change, stable isotopes, benthic foraminifera, grain sizes, North Sea, Skagerrak, HOLSMEER project.

\section{Introduction}

The assessment of future responses of the Earth's climate system to anthropogenic forcing is most severely inhibited by inadequate understanding of natural climate variability. The latter can be investigated on a number of different timescales reaching eg, from glacial/interglacial changes, driven by orbital forcing (Imbrie et al., 1984), to decadal variability, as expressed in the North Atlantic Oscillation (Hurrell, 1995; Marshall

*Author for correspondence (e-mail: dhebbeln@rcom-bremen.de) et al., 2001). An important time frame in this context is the late Holocene, spanning the last approximately 2000 years, during which human societies evolved at an ever increasing pace. Besides being affected by significant natural climate variability during this period, humans also started to change their environment, first on local, later on regional and finally on global scales.

The expression of climate change over the past millennia has been a matter of discussion for long time (see, eg, compilations in Jones et al., 2001 and Jones and Mann, 2004). The most often cited and probably most extreme among several explicitly 
described climate epochs are the relatively warm 'Mediaeval Warm Period' (MWP) followed by the relatively cold 'Little Ice Age' (LIA). There is an ongoing discussion about the overall nature of these periods and about their global or only regional expression (eg, Hughes and Diaz, 1994; Jones and Mann, 2004). However, there is some evidence from northern and central Europe for on average warmer conditions during the MWP followed by colder conditions during the LIA (eg, Grove, 2002; Jones and Mann, 2004), and it appears that these two epochs were the warmest (except the second half of the twentieth century), respectively the coldest periods in the Northern Hemisphere through the last two millennia (Jones and Mann, 2004). Both epochs have been variously dated and, being aware that there are large regional differences in the expression of these epochs (eg, Huntley et al., 2002), here we use the ranges of $\mathrm{AD} 800$ to $\mathrm{AD} 1400$ and $\mathrm{AD} 1400$ to $\mathrm{AD} 1900$ given by Jones and Mann (2004) to describe periods of generally warmer, respectively colder conditions in the Northern Hemisphere. Without adding to the discussion about the overall nature and expression of these climatic epochs, the terms MWP and LIA are used here as they are useful and convenient terms to describe these two intervals characterized by particular patterns of their climatic conditions (Huntley et al., 2002).

Climate variability over the past millennia has been convincingly demonstrated using documentary evidence and historical data, together with terrestrial proxies, notably tree rings, lake records, ice-cores and speleothem, as well as marine proxies. However, marine records providing a temporal resolution high enough to allow detailed reconstructions of the palaeoenvironment over the last 2000 years are scarce, because in open marine settings sedimentation rates are mostly too low, whereas in shelf settings continuous sedimentation mostly is restricted to very few locations. Nevertheless, such locations do exist and, in contrast to open marine records, they have the potential to provide detailed records (decadal time resolution or better) of both the marine and the terrestrial palaeoenvironment.

The North Atlantic plays an important role in the Earth's climate system and, consequently, is a prime target for the reconstruction of late Holocene paleoenvironments. In this region, a crucial site to study the interaction of the open marine and the more continental setting is the Skagerrak (Figure 1), where the Baltic Sea is connected to the North Sea and, eventually, to the North Atlantic. There, almost unaltered North Atlantic as well as modified North Sea waters meet relatively fresh Baltic Sea outflow waters (Longva and Thorsnes, 1997; Rodhe, 1998) strongly affected by precipitation in northern Europe. Most of the sediment load from all these water masses is eventually deposited in the Skagerrak, making this basin the major sink for fine-grained sediments in the North Sea region (Longva and Thorsnes, 1997). Because of the complex circulation system of the North Sea, sedimentary records of environmental changes may be differently manifested in different parts of this area, thus, palaeoenvironmental studies of these marine records require regional consideration. Some palaeoenvironmental reconstructions from the Skagerrak covering the last $\sim 2000$ years exist (Hass, 1996; Nordberg, 1991) and provide detailed information on specific topics and/ or sites. Here, we follow a regional multiproxy approach focusing on high-resolution marine records from the Skagerrak, but also including data from the Norwegian continental slope and from the southern North Sea. The aim is to reconstruct the inter-relationships between climate forcing, oceanic circulation and terrestrial response in this part of the critical North Atlantic region prior to significant anthropogenic forcing of the environment.

\section{Regional setting}

The modern circulation pattern in the North Sea is mainly driven by the inflow of Atlantic waters between Scotland and Norway (Figure 1). This inflow stimulates a counterclockwise circulation in the North Sea, with parts of the Atlantic water following the depth contours in the northern North Sea, namely as the Tampen Bank Current (TBC) and the Southern Trench Current (STC) (Rodhe, 1998). Part of the Atlantic water flows around the entire North Sea, where its properties are modified, eg, by freshwater supplied by numerous large rivers such as the Thames, Rhine, Elbe and Weser. Finally, this modified North Sea water runs up the Danish coast as the South Jutland Current (SJC) and continues as the North Jutland Current (NJC) into the Skagerrak. In the eastern Skagerrak, the North Jutland Current and Southern Trench Current waters are supplemented by less saline Baltic outflow water, the Baltic Current (BC). These combined waters turn towards northwest and west to form the Norwegian Coastal Current (NCC), which continues northward along the Norwegian coast (Longva and Thorsnes, 1997; Rodhe, 1998) (Figure 1).

This North Sea circulation pattern is also related to the large-scale atmospheric circulation system. For example, strong westerly winds enhance the currents, whereas easterly wind directions hamper the water mass circulation (Dooley and Furnes, 1981). This is even more obvious for the Skagerrak, where (i) the strength of the South Jutland Current, and thus the supply of sediment-laden North Sea waters, is largely dependent on the regional wind stress over the southern North Sea (Rodhe, 1996), and where (ii) also the bottom current velocities respond to changing wind fields (Longva and Thorsnes, 1997). Thus, atmospheric forcing also plays an important role in the dynamics of the North Sea.

The shallow North Sea (on average $<100 \mathrm{~m}$ water depth, Figure 1) is characterized by high tidal and wave-energy levels and, consequently, continuous sediment redistribution is a dominant process. There are only a few depocentres where sustained sediment deposition, the precondition for any meaningful palaeoenvironmental reconstruction, occurs (Lohse et al., 1995). Among these, the Skagerrak with a maximum depth of about $700 \mathrm{~m}$ is the most important depocentre in the entire North Sea and its sediment sequences have been used for many palaeoenvironmental studies (eg, Stabell and Thiede, 1985; Nordberg, 1991; van Weering et al., 1993; Conradsen and Heier-Nielsen, 1995; Knudsen et al., 1996), however, only a few have focused on the late Holocene (eg, Hass, 1993, 1996).

The current system in the Skagerrak forms an anti-clockwise circulation pattern that is part of the North Sea circulation pattern as described above. Both the surface and bottom currents in the Skagerrak generally follow this pattern, however with lower bottom current velocities compared with the surface waters (Dahl, 1978; Qvale and van Weering, 1985; Rodhe, 1987). Most of the bottom waters are of North Atlantic origin with only a minor contribution of dense winter water formed in the shallow northern North Sea during very cold winters (Ljøen and Svansson, 1972). In general, the highest bottom current velocities occur on the convex southern slope of the Skagerrak (Rodhe, 1987), to which the inflowing water masses are constrained.

A second, but less important depocentre in the North Sea is the Helgoland mud area in the German Bight (von Haugwitz 


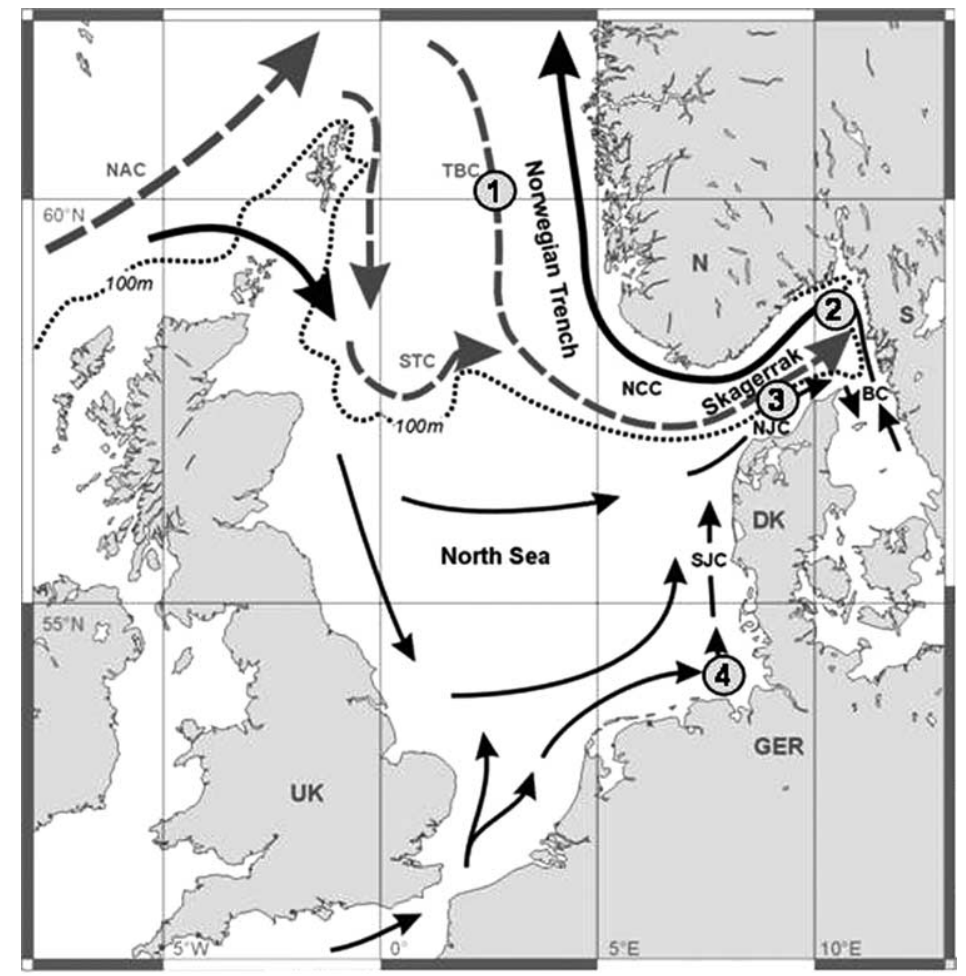

Figure 1 Selected core locations for this study: 1, HM115-16 from the Norwegian margin; 2, MD99-2286 and 3, GeoB 6003-2 from the Skagerrak; and 4, GeoB 4801-1 from the Helgoland mud area. The map also shows a general circulation pattern for the North Sea with the major currents abbreviated as NAC, Norwegian Atlantic Current; STC, Southern Trench Current; TBC, Tampen Bank Current; SJC, South Jutland Current; NJC, North Jutland Current; BC, Baltic Current; and NCC, Norwegian Coastal Current. Modified from Danielssen et al. (1991) and Nordberg (1991)

et al., 1988). Its potential as an archive for palaeoenvironmental reconstructions has been proved by Hebbeln et al. (2003) and Scheurle et al. (2005).

\section{Material and methods}

This study focuses on the Skagerrak in the NE North Sea with two strategically chosen sediment core sites, one in the southern Skagerrak (GeoB 6003-2) reflecting merely the advection of Atlantic waters to the area, and one in the northeastern Skagerrak (MD99-2286) situated in the path of the Baltic outflow (Figure 1, Table 1). Additional information is taken from core sites in the German Bight (GeoB 4801-1) and at the Norwegian margin (HM115-16) (Figure 1, Table 1).

Most analyses concentrated on the two cores from the Skagerrak. Core GeoB 6003-2 was analysed for its chemical composition using the Bremen X-ray fluorescence (XRF) Core Scanner, which allows a semi-quantitative determination of the contents of major and minor elements by scanning split sediment cores in a non-destructive way (eg, Jansen et al., 1998; Röhl et al., 2000). Here we use $\mathrm{Ca}$ and $\mathrm{K}$ contents measured at $1 \mathrm{~cm}$ resolution. The semi-quantitative data (given in counts per second) are displayed here as the $\mathrm{Ca} / \mathrm{K}$ ratio and used as an indicator for the composition of the sediments. Whereas $\mathrm{Ca}$ is often used as a proxy for the content of biogenic carbonate (eg, foraminifera, coccoliths, see for example Jennerjahn et al., 2004), $\mathrm{K}$ can be used as a proxy for its main mineralogical carrier illite (eg, Kuhlmann et al., 2004).

Diatom preparation and counting were conducted following standard procedures as described by Battarbee (1973), Schrader and Gersonde (1978), Fenner (1981) and Abrantes (1988). For both cores in the Skagerrak the summer sea surface salinity (SSS) has been reconstructed based on diatom transfer functions that rely on a diatom-environmental variable data set from the Skagerrak-Kattegat showing that the distribution of the surface sediment diatom assemblages is clearly correlated with modern environmental parameters, especially with the summer SSS (Jiang, 1996). For our reconstructions, an extended data set with additional samples from the northern part of the Skagerrak and from the Baltic Sea has been used (H. Jiang, unpublished data, 2002). In addition, for core GeoB 6003-2, also the diatom accumulation rate has been calculated as valves per square centimetre per year, according to Abrantes (1988).

Table 1 Overview of the sediment cores used for this study

\begin{tabular}{llrr}
\hline Core & Latitude & Longitude $^{2}$ & Water depth (m) $^{\text {Reference }}$ \\
\hline GeoB 4801-1 & $54^{\circ} 06.7^{\prime} \mathrm{N}$ & $08^{\circ} 02.2^{\prime} \mathrm{E}$ & 25 \\
GeoB 6003-2 & $57^{\circ} 58.3^{\prime} \mathrm{N}$ & $09^{\circ} 23.2^{\prime} \mathrm{E}$ & 312 \\
HM115-16 & $60^{\circ} 52.0^{\prime} \mathrm{N}$ & $03^{\circ} 440^{\prime} \mathrm{E}$ & 338 \\
MD99-2286 & $58^{\circ} 43.8^{\prime} \mathrm{N}$ & $10^{\circ} 12.3^{\prime} \mathrm{E}$ & 3 \\
\hline
\end{tabular}

a1, Hebbeln et al. (2003); 2, Scheurle (2004); 3, D. Klitgaard-Kristensen, H.P. Sejrup, M. Smelror, H.J.B. Birks and H. Haflidason, unpublished data, 1997; 4, Gyllencreutz et al. (2005). 
For grain-size analyses, the sediment samples were wetsieved over a $63 \mu \mathrm{m}$ sieve. For core MD99-2286 more detailed analyses were performed on the untreated fine fraction (1-63 $\mu \mathrm{m})$ using the sedigraph technique, as described in detail for this core by Gyllencreutz (2005). Organic carbon and carbonate were not removed from the samples but their contents were measured. No significant correlation was found between the grain-size parameters discussed here and carbonate content (Gyllencreutz, 2005) or organic carbon content (R. Gyllencreutz, unpublished data, 2005). Shown in this paper (see Figure 4) is the median of the sortable silt fraction (10-63 $\mu \mathrm{m})$, which according to McCave et al. (1995) can be used as a proxy for relative bottom current speed.

In order to obtain the best possible comparison with previous foraminiferal analyses in the area, the samples were sieved over a $100 \mu \mathrm{m}$ sieve, and foraminifera in the size fraction $>100 \mu \mathrm{m}$ were concentrated using the heavy liquid $\mathrm{CCl}_{4}(\rho=$ $1.59 \mathrm{~g} / \mathrm{cm}^{3}$ ) as described by Meldgaard and Knudsen (1979). Calcareous benthic foraminifera, which were generally well preserved, form the major part of the fauna. The planktic foraminifera fauna consists of small-sized specimens of only a few species. Where possible, at least 300 specimens of benthic calcareous foraminifera were identified and counted in each sample. Only the most interesting species with respect to the palaeoenvironment in the Skagerrak are discussed here. The accumulation rates (or fluxes) of all benthic and planktic foraminifera are calculated from the total number of individuals $>100 \mu \mathrm{m}$ per gram sediment, the dry bulk density of the sediment and the estimated sedimentation rates.

Stable oxygen $\left(\delta^{18} \mathrm{O}\right)$ and carbon $\left(\delta^{13} \mathrm{C}\right)$ isotopes have been analysed on all the cores listed in Table 2 . The measurements of benthic as well as planktic foraminifera shells have been conducted in the laboratories in Bergen, Bremen and Stockholm following standard procedures described elsewhere (eg, Klitgaard-Kristensen et al., 2001; Scheurle and Hebbeln, 2003). The basic parameters of the analyses discussed here are summarized in Table 2. The use of different species of benthic foraminifera is linked to the different settings of the investigated cores ranging from very shallow habitats (eg, $25 \mathrm{~m}$ water depth for core GeoB 4801-1) via a basin setting in the Skagerrak (cores GeoB 6003-2 and MD99-2286) to an open slope setting along the Norwegian margin (core HM115-16), resulting in very different benthic foraminiferal assemblages.

Furthermore, for the Norwegian margin core (HM115-16), sea surface temperature (SST) and salinity (SSS) reconstructions have been carried out using dinoflagellate transfer functions (M. Smelror, D. Klitgaard-Kristensen, H.P. Sejrup and H.J.B. Birks, unpublished data, 2004). This reconstruction is based on the dinoflagellate data base consisting of 439 samples from the North Atlantic compiled by Rochon et al. (1999). Weighted Average Partial Least Square (WAPLS) in the software program C2 (http://www.campus.ncl.ac.uk/staff/
Stephen.Juggins/software.htm) has been used as the statistical method combining sea surface salinity and temperature for both February and August. Statistically, the August salinity and surface temperature presented here have error estimates of $1.9 \mathrm{psu}$ and $2.7^{\circ} \mathrm{C}$. We are aware that the amplitudes of the reconstructed salinity and temperature changes in the dinoflagellate record are within the same range as the error estimates from the transfer function calculations, hence it seems that no significant changes can be extracted from the record. However, the large error estimates may be related to the transfer function method. One issue that could explain this is the data base used (Rochon et al., 1999) that has only a low density of samples from our study region and thereby lacks good analogues. Improving the data base with better coverage from the North Sea region probably would enhance the statistical performance. Nevertheless, as the data reveal a clearly structured record through time that also fits to, eg, the benthic $\delta^{18} \mathrm{O}$ record of the same core, we are confident that the SST and SSS data can be used as indicators for past water mass variability off Norway.

\section{Age models}

The age models of the cores used here are principally based on AMS ${ }^{14} \mathrm{C}$ as well as ${ }^{210} \mathrm{~Pb}$ analyses. Some of these have already been published (GeoB 4801-1: Hebbeln et al., 2003; MD992286: Gyllencreutz, 2005). For the other cores, the ${ }^{210} \mathrm{~Pb}$-based age estimates were obtained by measuring the ${ }^{210} \mathrm{~Pb}$ activity via its $\alpha$-particles-emitting grand-daughter ${ }^{210} \mathrm{Po}$, following the method described by van Weering et al. (1987). The AMS ${ }^{14} \mathrm{C}$ datings were made at the Leibniz Laboratory for Age Determinations and Isotope Research at the University of Kiel (Nadeau et al., 1997) and at the Poznan Radiocarbon Laboratory at the Adam Mickiewicz University in Poland (Table 3). The ${ }^{14} \mathrm{C}$ ages of core HM115-16 were calibrated by using CALIB version 5.0 (based on marine INTCAL04; Hughen et al., 2004), whereas for the dates from core GeoB 6003-2 the CALIB4 programme (Stuiver et al., 1998), applying the marine model calibration curve has been used. For all ${ }^{14} \mathrm{C}$ ages a marine reservoir age of 400 years has been used as described for Danish waters by Heier-Nielsen et al. (1995).

The ${ }^{210} \mathrm{~Pb}$ activity in the upper $40 \mathrm{~cm}$ of core GeoB $6003-2$ decreases significantly downcore, enabling an estimation of the sedimentation rate $(1.8 \mathrm{~mm} / \mathrm{yr})$ for the last $\sim 200$ years, characterized by rather unconsolidated sediments (Figure 2). Further downcore the AMS ${ }^{14} \mathrm{C}$ dates obtained between 283 $\mathrm{cm}$ and $446 \mathrm{~cm}$ core depth line up nicely and indicate a constant sedimentation rate of $\sim 1.65 \mathrm{~mm} / \mathrm{yr}$. The extrapolation of the sedimentation rate of $1.65 \mathrm{~mm} / \mathrm{yr}$ towards the core top points to a decrease in sedimentation rate in the younger part of the core, as the ${ }^{210} \mathrm{~Pb}$ data indicating recent sediments

Table 2 Overview of the stable isotope analyses carried out for this study.

\begin{tabular}{|c|c|c|c|c|c|}
\hline Core & Species & No. of tests & Size $(\mu \mathrm{m})$ & Lab & Reference $^{\mathrm{a}}$ \\
\hline GeoB 4801-1 & Elphidium excavatum $f$. selseyensis & $10-20$ & $>150$ & Bremen & 5,6 \\
\hline GeoB 6003-2 & Globigerinita uvula & $\sim 150$ & $>100$ & Bremen & 2 \\
\hline GeoB 6003-2 & Melonis barleeanus & $10-20$ & $>100$ & Bremen & 2 \\
\hline HM115-16 & Uvigerina mediterranea & $1-2$ & $>125$ & Bergen & 3 \\
\hline MD99-2286 & Melonis barleeanus & $3-8$ & $>100$ & Stockholm & 4 \\
\hline
\end{tabular}

Analytical standard deviations for these measurements are about $\pm 0.07 \%$ PDB for $\delta^{18} \mathrm{O}$ and $\pm 0.06 \%$ PDB for $\delta^{13} \mathrm{C}$ for the three Isotope Laboratories at the Bremen, Bergen and Stockholm Universities.

a2, Scheurle (2004); 3, D. Klitgaard-Kristensen, H.P. Sejrup, M. Smelror, H.J.B. Birks and H. Haflidason (unpublished data, 2004); 4, K.L. Knudsen et al. (unpublished data, 2005); 5, Scheurle and Hebbeln (2003); 6, Scheurle et al. (2005). 
Table 3 AMS ${ }^{14} \mathrm{C}$ dates for the cores GeoB 6003-2 from the southern Skagerrak and HM115-16BC and HM115-16GC from the Norwegian margin

\begin{tabular}{|c|c|c|c|c|c|c|c|c|}
\hline $\begin{array}{l}\text { Core } \\
\text { depth }(\mathrm{cm})\end{array}$ & Lab. ID & Material & $\begin{array}{l}{ }^{14} \mathrm{C} \\
\text { ages (BP) }\end{array}$ & Error $( \pm)$ & $\begin{array}{l}\text { Reservoir } \\
\text { corrected } \\
\text { ages (BP) }\end{array}$ & $\begin{array}{l}\text { Calibrated ages } \\
\text { (cal. yr BP) }\end{array}$ & $\begin{array}{l}\text { Min/max } \\
\text { range; } 1 \sigma\end{array}$ & $\delta^{13} \mathrm{C}$ \\
\hline \multicolumn{9}{|c|}{ GeoB 6003-2 } \\
\hline 283 & KIA 18238 & mix. benth. for. & 2400 & 35 & 2000 & 2020 & $+53 /-40$ & -9.8 \\
\hline 343 & KIA 18236 & mix. benth. for. & 2690 & 30 & 2290 & 2345 & $+22 /-14$ & -2.6 \\
\hline 403 & KIA 13694 & mix. benth. for. & 2875 & 30 & 2475 & 2692 & $+15 /-30$ & 0.1 \\
\hline 446 & KIA 18926 & shell fragment & 3190 & 30 & 2790 & 2968 & $+55 /-34$ & +1.1 \\
\hline \multicolumn{9}{|c|}{$H M 115-16 B C$} \\
\hline $18.9-19.8$ & Poz-6403 & N. pachy. (dex.) & 1150 & 150 & 750 & 690 & $95 /-180$ & \\
\hline $20.4-21.6$ & KIA 20091 & N. pachy. (dex.) & 1005 & 30 & 605 & 585 & $+35 /-35$ & -0.32 \\
\hline $28.2-29.1$ & Poz-6404 & N. pachy. (dex.) & 990 & 30 & 590 & 580 & $+40 /-35$ & \\
\hline $35.7-36.6$ & KIA 20092 & N. pachy. (dex.) & 1115 & 30 & 715 & 665 & $+25 /-35$ & -3.72 \\
\hline \multicolumn{9}{|c|}{$H M 115-16 G C$} \\
\hline $18-19$ & Poz-6405 & N. pachy. (dex.) & 1040 & 35 & 640 & 630 & $+40 /-20$ & \\
\hline $39-42.5$ & Poz-6487 & N. pachy. (dex.) & 2035 & 45 & 1635 & 1600 & $+60 /-70$ & \\
\hline
\end{tabular}

The measurements made in Kiel (KIA) and in Poznan (Poz) are based on samples consisting of mixed benthic foraminifera (mix. benth. for.), of shell fragments or of monospecific assemblages of the planktic foraminifera Neogloboquadrina pachyderma (dextral).

at the core top exclude a core top hiatus. The presumed drop in sedimentation rate has been aligned with a significant increase in coarse fraction $(>63 \mu \mathrm{m}$ wt. $\%$ ) in $135 \mathrm{~cm}$ core depth (Figure 2). This increase is interpreted as an indicator for the enhancement of bottom currents resulting in enhanced winnowing and, thus, in a lower sedimentation rate. Consequently, from this level, with an extrapolated age of $c .1050 \mathrm{cal}$. yr BP, towards the core top a lower sedimentation rate of $1.2 \mathrm{~mm} / \mathrm{yr}$ has been estimated.

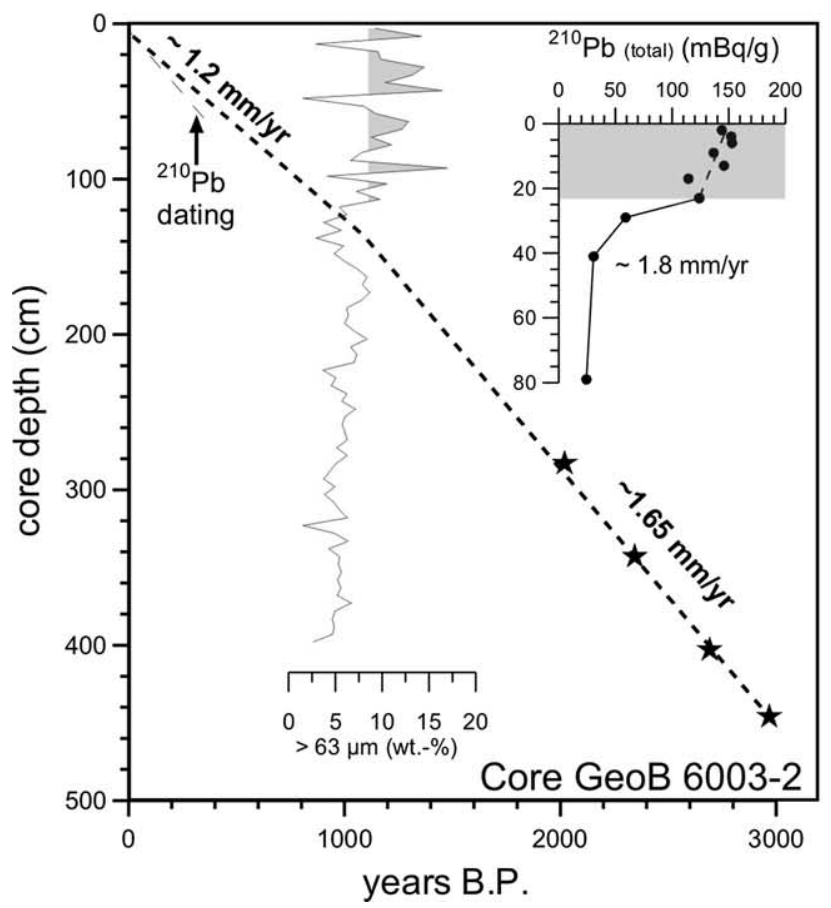

The chronology of site HM115-16 is based on a combination of the box core HM115-16BC and the gravity core HM11516GC (Table 3). In core HM115-16BC, it is clear that the four AMS radiocarbon dates overlap by one standard deviation making any stratigraphic interpretation difficult. In core HM115-16GC, the two AMS ${ }^{14} \mathrm{C}$ dates point to a sedimentation rate of $\sim 23 \mathrm{~cm} / \mathrm{kyr}$. The two cores have been correlated by the relative abundance of the benthic foraminifera Trifarina angulosa (Figure 2). The change in the relative abundance of

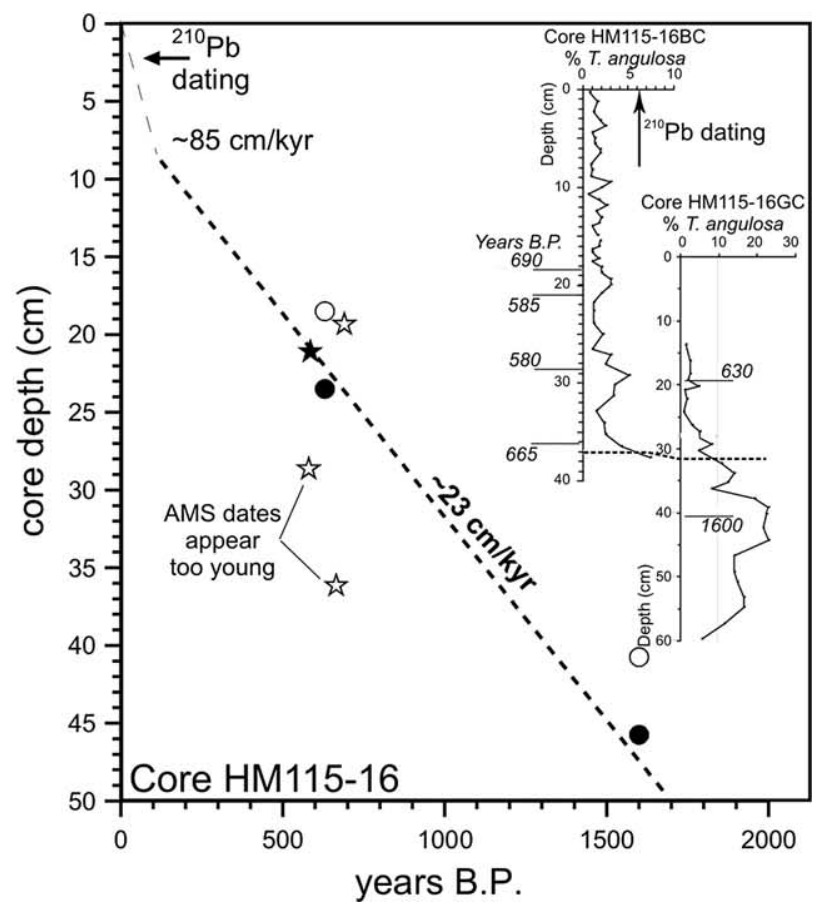

Figure 2 Left panel. Age model for core GeoB 6003-2 from the southern Skagerrak. The inset in the upper right shows the ${ }^{210} \mathrm{~Pb}$ data versus core depth. The shading in the upper $\sim 20 \mathrm{~cm}$ indicates the mixed layer at the surface. The decrease in ${ }^{210} \mathrm{~Pb}$ further downcore indicates a sedimentation rate of $\sim 1.8 \mathrm{~mm} / \mathrm{yr}$. The stars indicate the AMS ${ }^{14} \mathrm{C}$ dates obtained for the lower part of the investigated section that line up resulting in a sedimentation rate of $\sim 1.65 \mathrm{~mm} / \mathrm{yr}$. The increase in the $>63 \mu \mathrm{m}$ fraction at $\sim 135 \mathrm{~cm}$ core depth is assumed to mark a decrease in sedimentation rate. Right panel. Age model for core HM115-16 from the Norwegian margin. The inset in the upper right shows the Trifarina angulosa records in both the box core (BC) and the gravity core (GC) from this site, used for correlation. The marked decrease in T. angulosa at $37 \mathrm{~cm}$ core depth in the $\mathrm{BC}$ and at $32 \mathrm{~cm}$ in the GC points to a depth offset of $5 \mathrm{~cm}$, probably resulting from coring disturbance during gravity corer deployment. The AMS ${ }^{14} \mathrm{C}$ dates are marked by stars for the $\mathrm{BC}$ and by circles for the GC. The open circles indicate the original data whereas the solid circles represent the GC dates shifted by $5 \mathrm{~cm}$ to align with the $\mathrm{BC}$ dates to the same depth scale. The final age model is based on linear interpolation using the solid circles and the solid star (see text) 
T. angulosa at $37 \mathrm{~cm}$ in HM115-16BC is regarded as similar to the change at $32 \mathrm{~cm}$ in HM115-16GC. Considering an offset in core depth of $5 \mathrm{~cm}$ between the box core and the gravity core, it appears that the AMS dates in the gravity core line up with the AMS date at $21 \mathrm{~cm}$ core depth in the box core (Figure 2), resulting in an average sedimentation rate of $\sim 23 \mathrm{~cm} / \mathrm{kyr}$ for both cores. Only for the very core top of the box core, higher sedimentation rates of $\sim 85 \mathrm{~cm} / \mathrm{kyr}$ are estimated, based on ${ }^{210} \mathrm{~Pb}$ dating for these rather unconsolidated sediments. This interpretation requires exclusion of the remaining AMS dates in the box bore, with the upper one being too old and the two lowermost dates being too young. Whereas the $18 \mathrm{~cm}$ date has a high standard deviation because of a small sample size, it is not clear what might have caused the seemingly too young ages for the dates at $29 \mathrm{~cm}$ and $36 \mathrm{~cm}$ core depth. However, the similar pattern of the T. angulosa record, found also in other nearby cores (Klitgaard-Kristensen et al., 2001), strongly supports the age model adopted here.

\section{Results and discussion}

\section{Surface water conditions in the Skagerrak}

Sea surface salinity (SSS) reconstructions from the southern Skagerrak show a trend towards decreasing SSS through the last 2000 years (Figure 3), although the record is incomplete because of two core sections marked by strong diatom dissolution prohibiting a meaningful interpretation of the diatom data. In this record the trend towards lower SSS is punctuated by a step at $c$. AD 900. Before this change the SSS in the southern Skagerrak was on average 2 psu higher compared with the northeastern site, while afterwards at both sites SSS varied around a similar level of 28.5 to $29 \mathrm{psu}$. In the northeastern Skagerrak, the salinity remained basically on a stable level of $\sim 28.5$ psu through the last 2000 years. However, two events marked by very low SSS (AD 1000 to $\mathrm{AD} 1200$ and $\mathrm{AD} 1400$ to $\mathrm{AD} 1520$ ) are recorded and most likely reflect enhanced outflow of low saline Baltic Sea water.

The stable oxygen isotope $\left(\delta^{18} \mathrm{O}\right)$ data measured on planktic foraminifera are also linked to SSS, but in addition they depend on sea surface temperatures (SST). At site GeoB 60032 the $\delta^{18} \mathrm{O}$ record obtained on the planktic foraminifera species G. uvula (Ehrenberg) shows rather heavy values (ie, high SSS and/or low SST) between AD 300 and AD 600 (Figure 3). As the diatom-based SSS reconstructions do not indicate higher salinities, the high $\delta^{18} \mathrm{O}$ data probably point to lower SSTs during this interval. This is, in principle agreement with an alkenone-based SST record from the southern Skagerrak indicating a slight cooling $\left(0.7^{\circ} \mathrm{C}\right)$ slightly later at $\mathrm{AD} 500$ (Emeis et al., 2003). After AD 1000, light isotope data parallel the lowered SSS obtained from the diatom transfer functions and, thus, support these data. However, only a few data points are available for this period as the number of planktic foraminifera in the core became too low to allow any $\delta^{18} \mathrm{O}$ measurements. Interestingly, very low amounts of planktic foraminifera in core MD99-2286 prevented any such measurements at this site. As planktic foraminifera are sensitive to salinity, it appears that in the Skagerrak planktic foraminifera no longer thrive at salinities below $\sim 30 \mathrm{psu}$ (eg, Johannesen et al., 1994). The data imply that such conditions prevailed in the northeastern Skagerrak at least through the last 2000 years and in the southern Skagerrak since AD 1000.

\section{Palaeoproductivity in the Skagerrak}

The palaeoproductivity can be assessed by qualitative (eg, stable carbon isotopes, $\delta^{13} \mathrm{C}$ ) as well as by quantitative (eg, flux rates) proxies. In the southern Skagerrak the $\delta^{13} \mathrm{C}$ data of planktic as well as benthic foraminifera show a coherent pattern pointing to a significant long-term decrease in productivity as indicated by increasing $\delta^{13} \mathrm{C}$ values between $\mathrm{AD}$ 700 and AD 1500, with the most significant changes occurring between AD 700 and AD 900. In contrast, in the northeastern Skagerrak the available benthic $\delta^{13} \mathrm{C}$ data display relatively

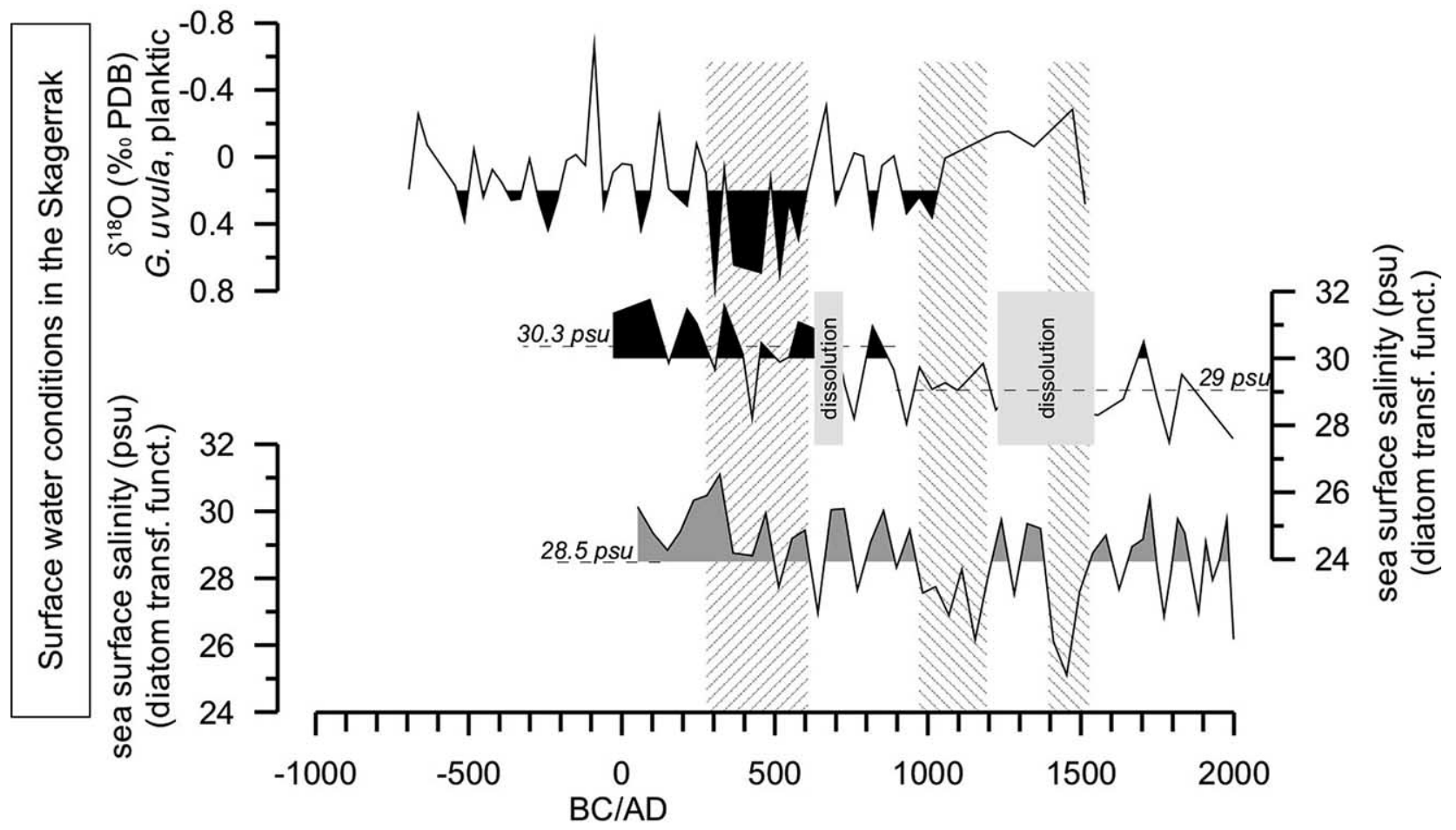

Figure 3 Proxies for the surface water conditions in the Skagerrak through the last 3000 years. Black curves display data from core GeoB 6003-2 in the southern and grey curves from core MD99-2286 in the northeastern Skagerrak. Hatched fields mark periods discussed in the text 


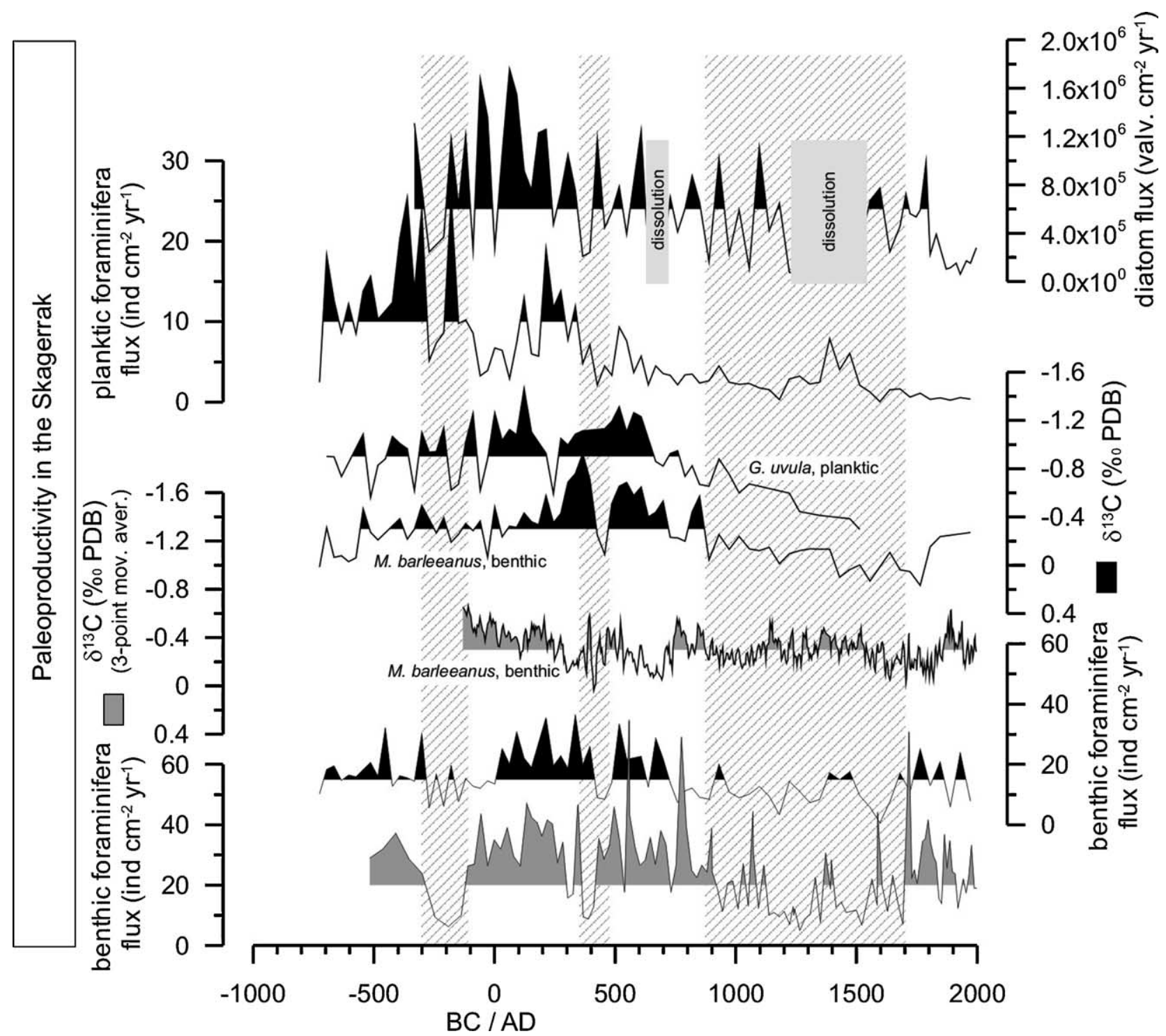

Figure 4 Proxies for the palaeoproductivity in the Skagerrak through the last 3000 years. Black curves display data from core GeoB $6003-2$ in the southern and grey curves from core MD99-2286 in the northeastern Skagerrak. At both sites the benthic $\delta^{13} \mathrm{C}$ data are obtained on $M$. barleeanus. Hatched fields mark periods discussed in the text

little variability (Figure 4). However, at both sites the flux rates of benthic foraminifera show a marked drop also between $A D$ 700 and $\mathrm{AD} 900$, with a subsequent increase to higher values at AD 1700. The diatom flux rates available for the southern Skagerrak also reveal a long-term trend towards lower fluxes. Also the planktic foraminifera flux mainly shows a long-term decrease. However, this might reflect a salinity effect rather than represent a palaeoproductivity signal (see above). In all flux records (and partly also in the $\delta^{13} \mathrm{C}$ data) there are two events marked by a sudden decrease in palaeoproductivity. These events occurred between $300 \mathrm{BC}$ and $100 \mathrm{BC}$, and around AD 400.

\section{Bottom water conditions in the Skagerrak}

Grain-size distributions and the composition of the sediments can provide information about the environmental setting at the sea floor with the strength of the prevailing bottom currents often leaving the most significant impact. Analyses of the sortable silt fraction in the northeastern Skagerrak core MD99-2286 reveal a clear step towards a coarser median of the sortable silt at AD 600 (Figure 5), which is accompanied by short-term maxima in the content of the $>63 \mu \mathrm{m}$ fraction.
After AD 600, the sortable silt median stays almost continuously at a high level, while the sand content $(>63 \mu \mathrm{m})$ reaches almost persistently higher values only after AD 900. Enhanced bottom current strength in the younger part of the record at this site, as indicated by the coarser sediments, is in agreement with data from the southern Skagerrak, also showing significantly increased percentages of the $>63 \mu \mathrm{m}$ fraction after AD 1000. At that site, the coarsening of the sediments comes along with a shift in composition, exemplified by increasing $\mathrm{Ca} / \mathrm{K}$ elemental ratios, which are supposed to reflect changes in the composition of the sediments, as eg, a decrease in very finegrained K-rich clay minerals after AD 900-1000. Also these data sets indicate short events prior to the major palaeoenvironmental shift around AD 900. At around $200 \mathrm{BC}$ and between $\mathrm{AD} 600$ and $\mathrm{AD} 750$ at both sites there are indications for shortterm enhancements of the bottom currents.

Variability in the bottom water conditions is also reflected in the species composition of the benthic foraminiferal fauna. Once more, the records indicate one major palaeoenvironmental shift and a number of abrupt events. However, the major palaeoenvironmental shift at around AD 900 occurs at different times for different species at the two sites. 


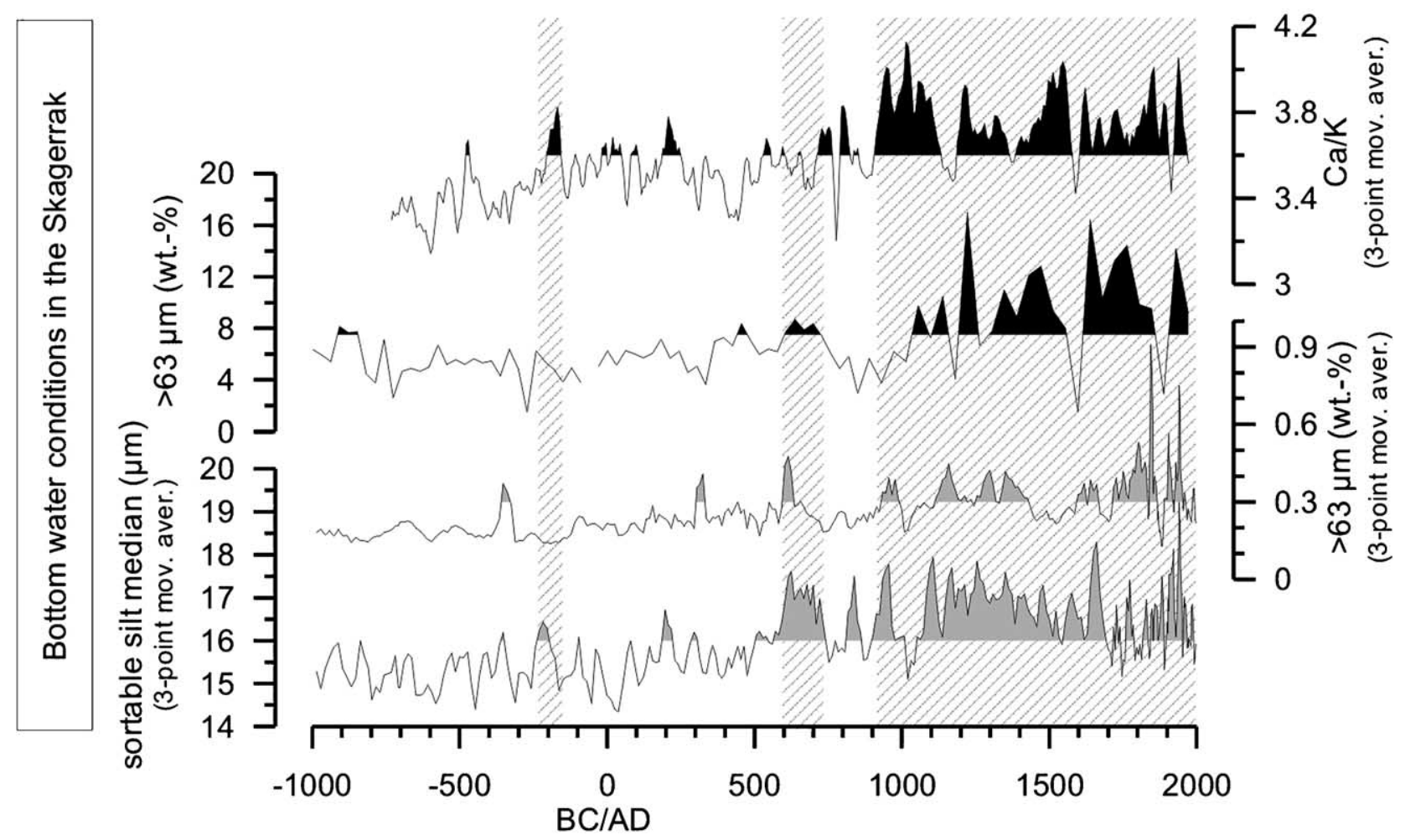

Figure 5 Proxies for the bottom water conditions in the Skagerrak through the last 3000 years. Black curves display data from core GeoB 6003-2 in the southern and grey curves from core MD99-2286 in the northeastern Skagerrak. Hatched fields mark periods discussed in the text

The first indication of this 'series of shifts', altogether reflecting the major palaeoenvironmental shift, is a sudden drop in the contribution by Hyalinea balthica (Schroeter) in the southern Skagerrak at around AD 750. This is followed in the northeastern Skagerrak by a major decrease in Bulimina marginata (d'Orbigny) and a considerable increase in Melonis barleeanus (Williamson) at around $\mathrm{AD} 850$, and in Cassidulina laevigata d'Orbigny at AD 1000 (Figure 6). Another significant transition occurs at $\mathrm{AD} 1150$, when, in the southern Skagerrak, the decrease in the contents of Pullenia osloensis (Feyling-Hanssen) and C. laevigata is balanced by an increase in Stainforthia fusiformis (Williamson) and the temperate form selseyensis (Heron-Allen and Earland) of Elphidium excavatum (Terquem). Over the last 100 years, another strong shift is indicated at the northeastern site by increasing percentages of B. marginata and decreasing contents of $C$. laevigata. Although both cores are from relatively nearby settings, the differences in water depth and in the environmental setting in the southern and in the northeastern Skagerrak result in partly opposite records in the relative abundances of individual species of benthic foraminifera, as exemplified here for $C$. laevigata (Figure 6). Thus, these differences hamper a direct comparison of the long-term development of individual species.

The general indication of the faunal shifts in the Skagerrak is associated with changes in the water masses of the area. The assemblages in the lower part of the record in the southern Skagerrak reflect relatively stable bottom water conditions under the influence of deeper Skagerrak water masses of Atlantic origin. The faunal composition found in this part of the record corresponds to modern assemblages living on the deeper parts of the southern slope of the Norwegian Trench (eg, C. laevigata, P. osloensis and H. balthica; see Conradsen et al., 1994; Bergsten et al., 1996). The subsequent change in assemblage at around $\mathrm{AD} 900$ is a result of increased environ- mental instability, presumably resulting from an intensification of the North Jutland Current. This is indicated by high amounts of the species $S$. fusiformis, together with an increase in shallow-water species such as E. excavatum, a species that is suggested to be reworked from the North Sea and Danish shelf areas (cf. Alve and Murray, 1995, 1997). In general, the assemblages in the upper part of the record correspond to the present-day faunas at the core site, which is in an area that is characterized by a relatively high influence of North Sea waters compared with the deeper part of the slope (eg, Bergsten et al., 1996).

In the northeastern Skagerrak core, the faunal compositions are quite different from those in the southern Skagerrak, but the faunal shift at around AD 900 is clearly a result of the same general environmental change in the area. The assemblages in the lower part of the northeastern Skagerrak record, characterized by an important contribution of B. marginata, correspond to modern faunas found further to the east along the Swedish west coast today (Conradsen et al., 1994). The faunal distribution in the lower part of the record shows that before AD 1000, this B. marginata province covered a wider area along the Swedish coast than at present. This is in agreement with results by Gyllencreutz and Kissel (2006). They found that magnetic properties of core MD99-2286 indicate stronger influence of the Baltic current and the currents along western Sweden and southern Norway before an abrupt change at about AD 900 than after. From AD 900 until the present, the sedimentation in the northeastern Skagerrak was totally dominated by southern North Sea and Atlantic Ocean sources (Gyllencreutz and Kissel, 2006).

After these major shifts (and despite the most recent shift after AD 1900) the mid-term variability in the faunal composition of the benthic foraminifera is comparably low, with only one strong signal between AD 1300 and AD 1500, best indicated by a sudden increase in Uvigerina mediterranea (Hofker) in the 


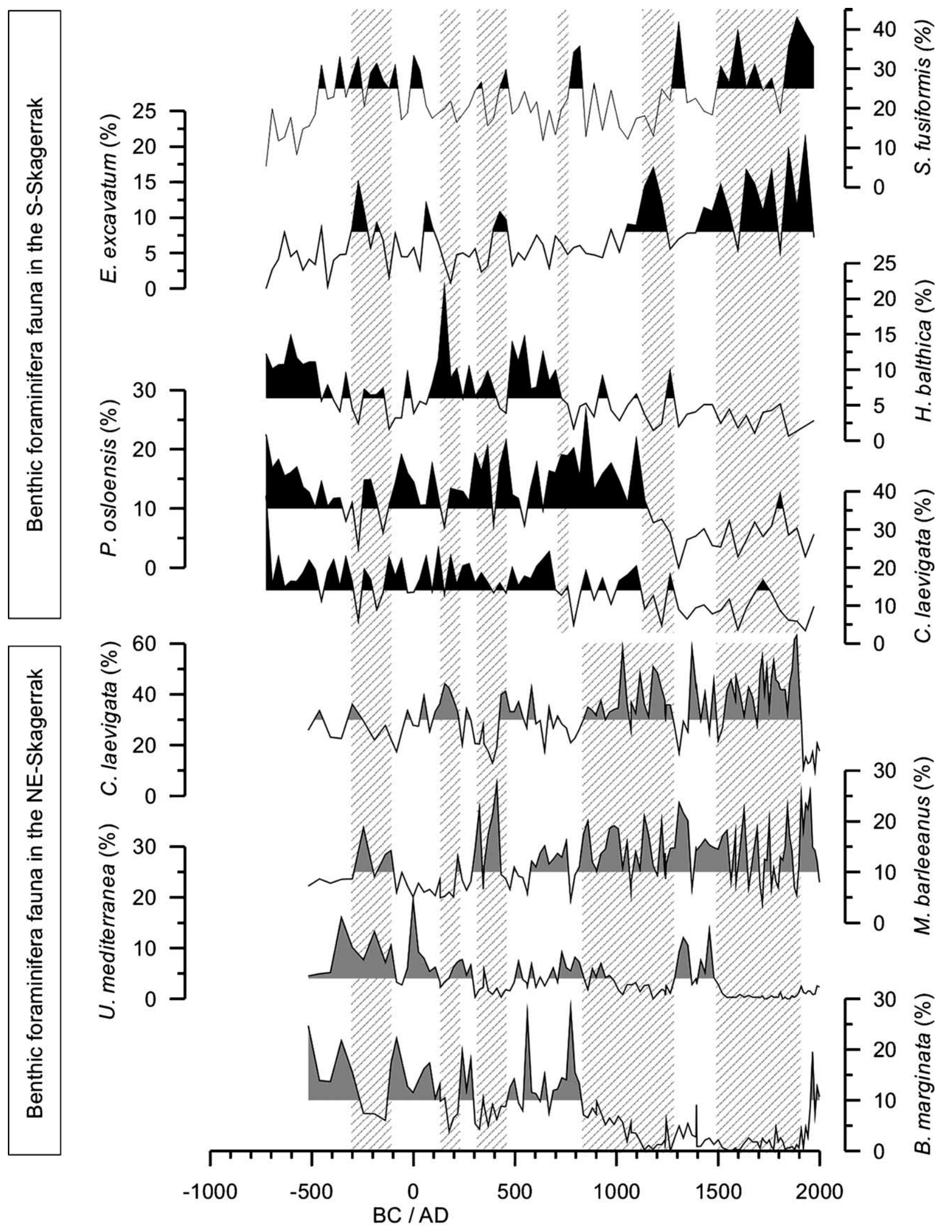

Figure 6 Relative abundances of selected benthic foraminifera in the Skagerrak through the last 3000 years. Black curves display data from core GeoB 6003-2 in the southern and grey curves from core MD99-2286 in the northeastern Skagerrak. Hatched fields mark periods discussed in the text

northeastern Skagerrak before this species vanished from the area. This event is probably also reflected in the diatom record, resulting in enhanced biogenic opal dissolution, which most likely took place at the sea floor. In addition, before AD 750 some events that left strong signals in the species composition occurred at both sites. The most pronounced events took place at 300 to $100 \mathrm{BC}$, around $\mathrm{AD} 200$ and between $\mathrm{AD} 300$ and $\mathrm{AD} 450$, however, all of these show different responses of the benthic fauna, preventing a straightforward interpretation of their causes. 


\section{Palaeoenvironmental conditions along the Norwegian margin and in the German Bight}

Core HM115-16 from the Norwegian margin represents the 'Atlantic end-member' in this compilation. Especially the benthic record, expected to be unaffected by the relatively fresh and shallow Norwegian Coastal Current reaching the core site occasionally, should be related to the strength of Atlantic water advection. After a smaller event centred around $\mathrm{AD} 500$, the benthic foraminifera $\delta^{18} \mathrm{O}$ data show a shift towards sustained lighter (ie, 'warmer') values around AD 900 (Figure 7) indicating an increase in the advection of Atlantic waters. After AD 1450 the isotope data returned to variable, but on average 'colder' values before displaying a marked increase through the last 50 years. Interestingly, this pattern is largely mirrored in surface water temperature and salinity reconstructions based on dinoflagellate transfer functions. These show, for the period AD 900 to AD 1450, marked by the light benthic $\delta^{18} \mathrm{O}$ data, relatively warm and saline surface waters also compatible with an increased strength of the North Atlantic Current. Subsequently, this appears to have been considerably weaker, as indicated by low SSS and SST values, probably related to further westward extension of the Norwegian Coastal Current. During the last 50 years, when the benthic isotope data reach the lightest values, the SSS record especially is marked by a strong increase, possibly related to another intensification of the Atlantic water advection.

In the German Bight the $\delta^{18} \mathrm{O}$ data are almost exclusively related to salinity variations as has been deduced from detailed correlations with instrumental records (Scheurle and Hebbeln, 2003). Thus, the $\delta^{18} \mathrm{O}$ data of core GeoB $4801-1$ provide a detailed salinity reconstruction for the German Bight, with salinity in this area being mainly dependent on the Elbe river discharge, which in turn gives a good integration of the precipitation in Central Europe (Scheurle et al., 2005). The available record spans the last 800 years and indicates three periods of relatively high salinities (ie, low discharges and low precipitation): AD 1300-1400, AD 1590-1650, and AD 1800-1920 (Figure 7).

\section{Regional integration of proxy data}

Apparent in all data sets covering the last 2000 years is a major environmental shift that took place between $\mathrm{AD} 600$ and AD 1100, with most of the changes taking place around AD 900 (Figure 8). At this time there is a strong increase in the advection of Atlantic waters recorded at the Norwegian margin site. As expected, this coincided with an intensification of the circulation in the North Sea as evidenced by a significant increase in bottom current strength in the Skagerrak. Although the sortable silt median gives an early indication for such an increase at $\mathrm{AD} 600$, the increase in sand content and the change in sediment composition reflected in changing $\mathrm{Ca} / \mathrm{K}$ ratio point to $\mathrm{AD} 900$ as the time of the most pronounced increase in bottom current strength. In addition, changes in the wind forcing over the North Sea can affect the bottom current strength along the slopes of the Skagerrak, which will increase

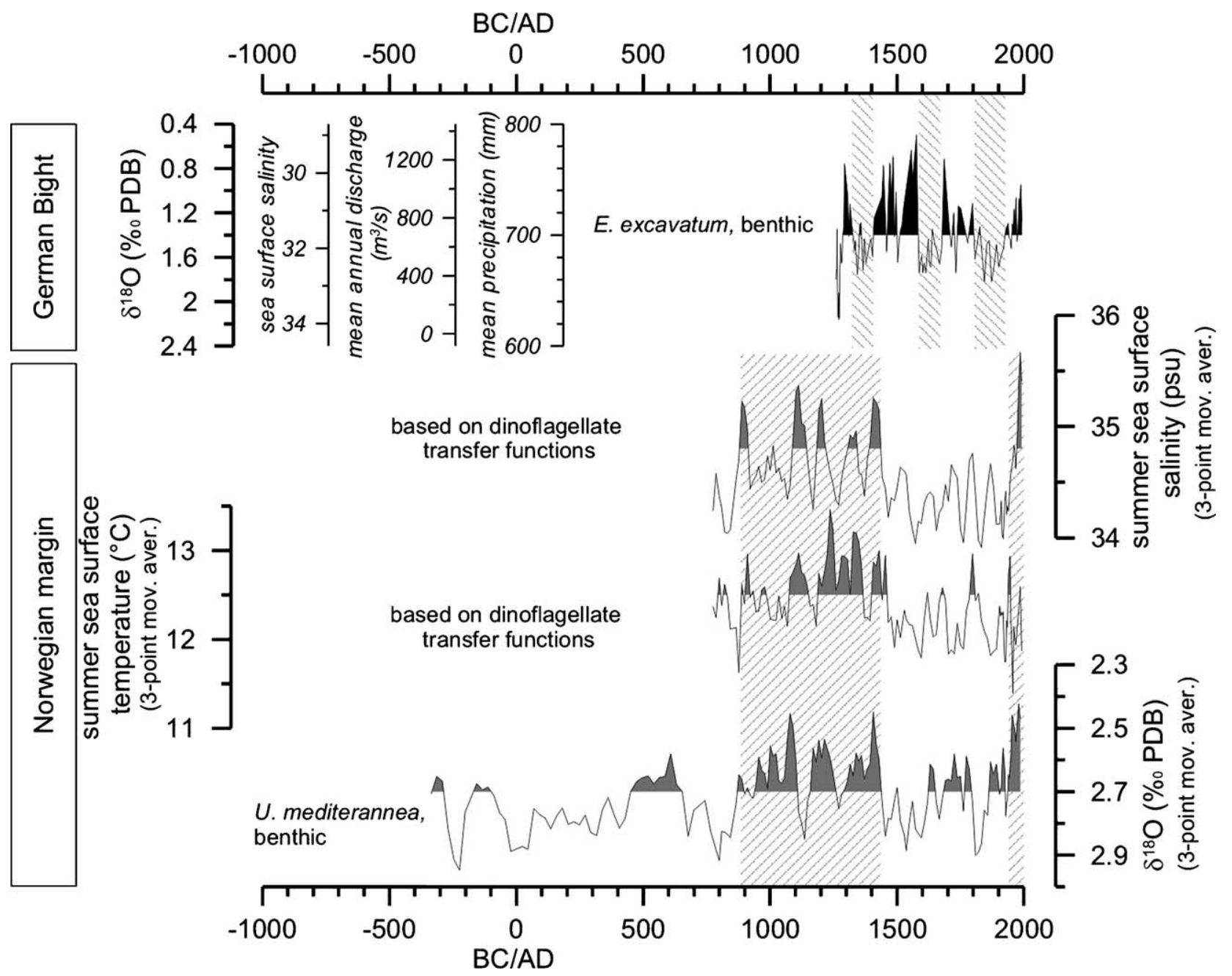

Figure 7 Proxies for the palaeoenvironmental conditions at the Norwegian margin (core HM115-16) and in the German Bight (core GeoB 4801-1). Hatched fields mark periods discussed in the text 


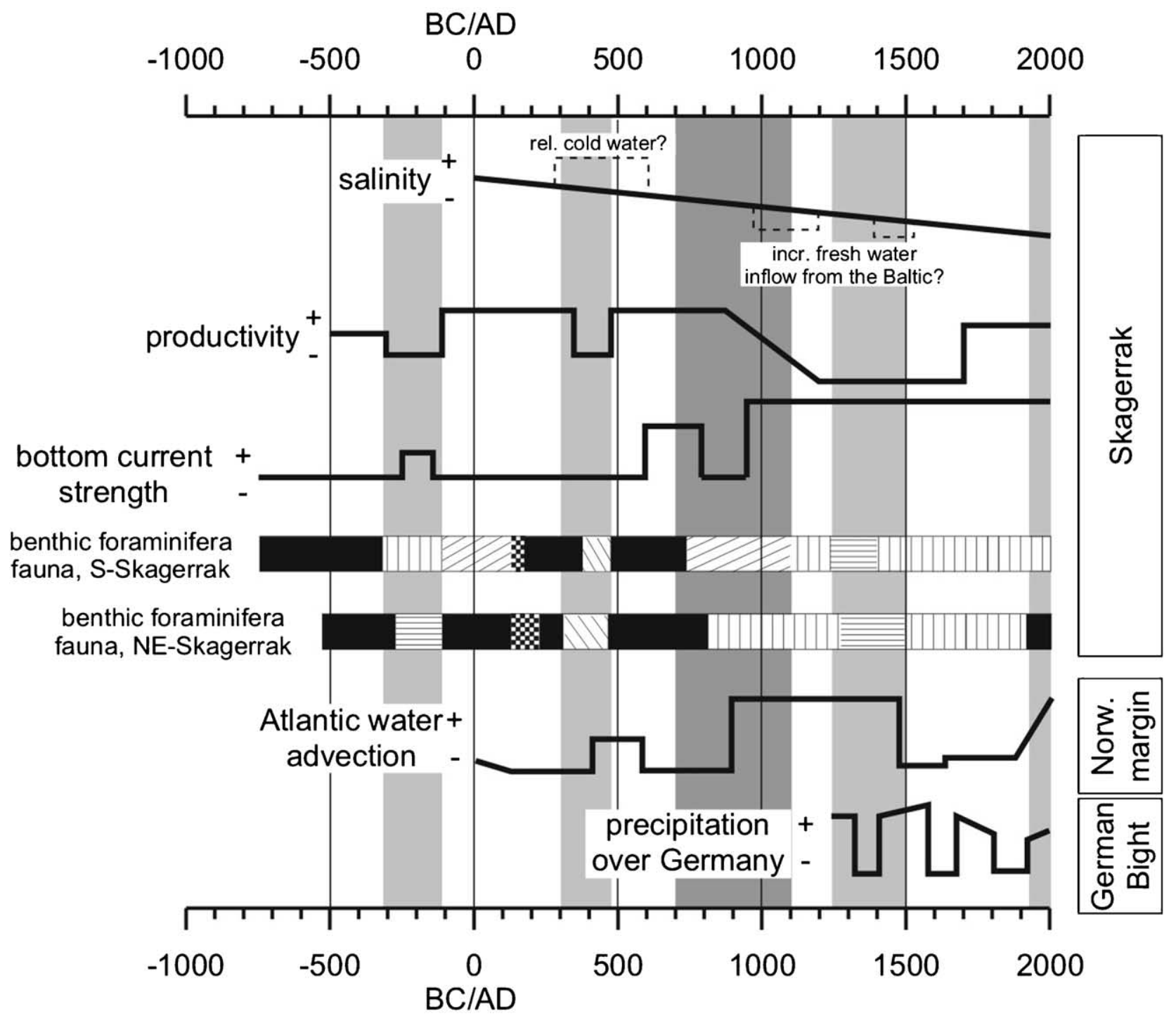

Figure 8 Schematic overview of the environmental changes in the North Sea region through the last 3000 years (see text for background). The coding for the two benthic foraminifera records is not linked as the assemblages are quite different. Vertical bars indicate events/periods in the environmental history (see text) and the major palaeoenvironmental shift between AD 700 and AD 1100

in response to strong southwesterly winds (Longva and Thorsnes, 1997).

Both forcing factors that most likely caused the coarsening of the sediments (Atlantic water advection and/or changes in the wind field) would also result in a strengthening of the South Jutland Current (Rodhe, 1996). This current, which flows northward along the shallow, sand-dominated Danish west coast, is the most erosive of the currents contributing to the Skagerrak sediments, and transports the highest concentrations of suspended sediment and, in particular, bedload (Eisma and Kalf, 1987). Thus, also an enhanced South Jutland Current could have contributed to the observed changes in grain size distribution and sediment composition. In a previous study of late Holocene sediments from the southwestern flank of the Skagerrak, Hass (1996) has also observed a distinct increase in the coarse fraction between AD 700 and AD 1000, which he explained to reflect the onset of modern circulation conditions in the North Sea during the early part of the 'Mediaeval Warm Period'.

The environmental change centred at AD 900 also resulted in a most pronounced change in the benthic foraminifera communities at both sites in the Skagerrak through the last 2500 years. In the southern Skagerrak, the benthic foramini- fera fauna shows a shift from a stable, Atlantic water-bound community, nowadays only present in deeper parts of the Skagerrak, to a more unstable community, often related to North Sea waters (Bergsten et al., 1996). Although counterintuitive at first glance, an intensification of the advection of Atlantic waters will not necessarily result in a larger body of true Atlantic water in the deep Skagerrak. Instead, the related overall enhancement of the North Sea circulation would stimulate a strengthening of the North Jutland Current that would push the boundary between North Sea water and true Atlantic water at the southern slope of the Skagerrak to a greater water depth. This would also explain the increasing numbers of probably reworked benthic foraminifera (eg, E. excavatum) originating from shallower settings (ie, Alve and Murray, 1995, 1997). In addition, the community change in the northeastern Skagerrak, marked by a drastic reduction of $B$. marginata, also would be in line with the interpretation of an enhanced circulation that probably pushed the $B$. marginata zone closer towards the Swedish coast and assemblages from more westerly areas of the Skagerrak immigrated into the core site area.

Also at around $\mathrm{AD} 900$ there is a clear decrease in the productivity in the Skagerrak, showing that not only the 
bottom but also the surface waters are affected by this shift. In addition, these surface waters are also affected by a long-term decrease in SSS.

Interestingly, the bottom current strength in the Skagerrak stays at a rather high level until the present, while the Atlantic water advection to the Norwegian margin (AD 1450), as well as the productivity in the Skagerrak (AD 1700), almost return to pre-AD 700 levels. The decreasing advection of Atlantic waters leaves only an enhanced wind forcing to explain the continued high bottom current velocities after AD 1450 .

In addition to this major environmental shift, there are several smaller events that leave their traces in a number of proxies. The first observed event occurred between $300 \mathrm{BC}$ and $100 \mathrm{BC}$ and is recorded in all proxies available for that period. At that time, a drop in productivity is associated with an increase in bottom current strength and a change in the benthic foraminifera fauna. The next event (AD 300 to $\mathrm{AD} 500$ ) is also marked by a lowered productivity, a change in the benthic foraminifera fauna and possibly colder surface waters in the Skagerrak, whereas the bottom current strength remains unaltered. An increase in the Atlantic water advection to the Norwegian margin commences slightly later, which could possibly be due to stratigraphic uncertainties.

After the major shift at AD 900, such events continue to happen, although later they are mostly reflected in the benthic foraminifera fauna, as eg, between AD 1250 and AD 1500, when the return of $U$. mediterranea to the northeastern site might be associated with an increase in temperature (cf. Murray, 1991), possibly because of a change in the water mass structure. The termination of this event coincides with the end of the period with very strong advection of Atlantic waters to the Norwegian margin, while at the same time a low salinity pulse in the Skagerrak points to enhanced Baltic Sea outflow, possibly associated with high continental precipitation as indicated in the German Bight core. Finally, at AD 1950 another increase in Atlantic water advection to the Norwegian margin goes along with a change in the benthic foraminifera fauna in the northeastern Skagerrak. However, the increase of B. marginata during the last 100 years in the Skagerrak is suggested to be a result of anthropogenic influence in the area (Seidenkrantz, 1993).

\section{Inferred environmental forcing}

In a previous assessment of the late Holocene palaeoenvironmental history of the Skagerrak, Hass (1996) concluded that climate changes associated with well-known climatic periods such as the 'Mediaeval Warm Period' (AD 700-1350, according to Hass, 1996) or the 'Little Ice Age' (AD 1350-1900, according to Hass, 1996) are the driving forces behind the observed changes in the Skagerrak. Hass relates warm periods (the MWP and the Roman Climate Optimum, 320 BC-AD 380) to weaker bottom currents, less Atlantic water advection and less wind forcing resulting from more northerly located cyclone tracks. Opposite conditions are assumed to dominate the colder phases (LIA and the Dark Ages, AD 400-700). These conclusions are drawn using subtle changes in grainsize distributions and stable oxygen isotope data. In addition, this data set also shows a marked and sustained coarsening of the sediments between AD 700 and AD 1000 (Hass, 1996), very similar to that described here. Hass (1996) related this to an intensified circulation system in the Skagerrak, however, without finding a relation to any climatic forcing.

Based on the results presented above, a different view on the inter-relation of the different forcing factors, as well as on their temporal development, can be constructed. Basically, the climate in northern Europe and particularly in the North Sea is closely related to the strength of the advection of warm and saline Atlantic waters to the region. Consequently, our records from the Norwegian margin should give an indication of this 'Atlantic-type' forcing. From the Norwegian margin record, it is clear that for most of the MWP (since AD 900) the region was affected by strong Atlantic water advection that continued well into the LIA (until AD 1450, see also Koç and Jansen, 2002). The onset of this event is in agreement with other records from the NE Atlantic and from the Icelandic shelf (eg, Eiríkson et al., 2006, this issue). However, at these sites a significant cooling, probably related to decreasing advection of Atlantic waters, began already at AD 1300, roughly at the turn from the MWP to the LIA.

As pointed out before, the onset of this Atlantic water advection event at AD 900 coincides with the permanent enhancement of bottom currents in the Skagerrak. Owing to a more northerly position of the Northern Hemisphere subtropical anticyclones during the MWP, westerly winds at latitudes between $40^{\circ}$ and $60^{\circ} \mathrm{N}$ were presumably weaker and less prevalent (Lamb, 1977). Therefore, the enhanced bottom current strength most likely resulted from the intensification of the North Sea circulation as outlined above, and not from wind stress. At first glance, one might also expect an associated temperature and salinity increase in the Skagerrak, however, the response appears to be much more complex. Almost at the same time as when the bottom water circulation in the Skagerrak intensified, the salinity in the surface waters decreased. The latter can be explained only by taking into account the consequences for the atmospheric circulation resulting from a warming of the North Atlantic. Indeed, in addition to the data shown in Figure 8, increased Atlantic sea surface temperatures have also been documented for other cores from the Norwegian margin in the time interval between about AD 1100 and AD 1450 (Koç and Jansen, 2002; Andersson et al., 2003, Klitgaard-Kristensen et al., 2004).

This warming probably resulted in enhanced evaporation over the ocean and enhanced precipitation over the continent. Much of the precipitation falling over northern Europe flows directly into the North Sea or into the Baltic Sea, from where the freshwater is canalized through the Kattegat and the Skagerrak to finally return to the Atlantic. Thus, a warming of the North Atlantic would result in enhanced freshwater flow to the North Sea and especially to the Skagerrak. Such a link between enhanced heat flux from the North Atlantic to the atmosphere and increased precipitation over the Baltic Sea catchment area has also been described by Emeis et al. (2003). Actually, such a pattern is indicated by the decreasing salinities in the Skagerrak surface waters and, even more pronounced, by the salinity minimum between AD 1400 and AD 1550, which coincides with increased precipitation over Germany (Figure 8).

The associated decrease in productivity in the Skagerrak might result from increased stratification of the water column between the fresher surface water and the deeper fully marine waters. Such stratification would hamper the delivery of nutrients from the deeper waters to the photic zone and thereby decrease the productivity. In addition, the much lower nutrient content of the low saline Baltic Sea outflow water (Rasmussen and Gustafsson, 2003) may also have contributed to the reduction in productivity.

At AD 1450, already well within the LIA, the advection of Atlantic waters to the Norwegian margin and consequently to the North Sea decreased. Interestingly, the response of the palaeoenvironment in the Skagerrak appears to be rather weak. The bottom sediments, as well as the benthic foraminifera, continue to indicate strong bottom currents and also the 
productivity remains at a low level, not returning to a somewhat higher level until AD 1700. Under such a weak Atlantic water advection scenario only enhanced atmospheric forcing (ie, stronger winds; Longva and Thorsnes, 1997) could explain the high bottom current velocities in the Skagerrak. And indeed, a southward shift of the cyclone tracks resulting from the expansion of the circumpolar vortex during the LIA, as suggested by Lamb (1977, 1979), would have resulted in stronger westerly winds and increased storm activity over the North Sea. This is supported by data from Björck and Clemmensen (2004) who interpreted aeolian sand influx in raised bogs in southwestern Sweden as an indication of increased winter storminess from c. AD 1450 to AD 1900 , preceded by about 700 years of low values. Thus, although forced by different factors before (the advection of Atlantic waters) and after (stronger winds and increased storminess) AD 1450, the strong bottom currents in the Skagerrak after AD 1000 can be related to the prevailing environmental conditions at the respective periods.

Of course, the next question is what caused the principal difference between the environmental setting prior to AD 7001000 (weak bottom currents) and afterwards (strong bottom currents). At first glance a climatic forcing appears unlikely, as eg, the strong bottom currents persisted through a warm period (MWP) as well as through a cold stage (LIA). However, if both settings are able to produce such strong bottom currents it might be the strength of the climatic variability playing the decisive role. Indeed, the two periods mentioned here are known as the warmest and coldest periods at least of the last 2000 years in this region (ignoring the period since the 1970s). Thus, it is possibly the strength of the respective forcing (MWP-oceanic versus LIA-atmospheric) that regulates bottom current velocities in the Skagerrak. Under a less extreme forcing, as eg, during the Roman Climate Optimum or the Dark Ages, the energy provided was probably insufficient to accelerate the bottom currents in the Skagerrak in a significant way. Looking beyond the MWP, our records show only one short period at the onset of the Roman Climate Optimum (300-100 BC, Figure 8), when probably a warm climate forcing was strong enough to enhance the North Sea circulation in a way similar to during the MWP.

At the present stage other causes for the observed palaeoenvironmental changes in the Skagerrak cannot be excluded. For instance, the sustained change in sediment composition at AD 900 might reflect a more local, climate-independent change, eg, in sediment source area, sediment transport pathways or coastal erosion intensity. According to Nordberg (1991), enhanced coastal erosion might have resulted in coarser sediments and in enhanced sedimentation rates in the Skagerrak at some time between $\mathrm{AD} 1000$ and $\mathrm{AD}$ 1500. However, at these times we found coarser sediments associated with lower sedimentation rates, indicative of increased winnowing by enhanced bottom currents. To our knowledge there are no independent hints for any local trigger of environmental variability in the Skagerrak region. In contrast, the evidence put together here from different sites in the North Sea all point to a major environmental shift at AD 900 affecting surface as well as bottom waters in the Skagerrak and at the Norwegian margin and are, thus, supportive of a more regional, ie, climatic trigger.

Finally, although the strong winds of the LIA are suggested to cause strong bottom currents in the Skagerrak after AD 1450, when the advection of Atlantic waters to the Norwegian margin decreased, it has to be noted that none of the records from the Skagerrak gives any clear hint indicating the transition from the MWP to the LIA. In contrast, increasing productivity in the Skagerrak at AD 1700, coinciding with an increase in northern Fennoscandian summer temperature anomalies (Briffa et al., 1992), might indicate the end of the LIA in the Skagerrak, although there is no related signal found in the Norwegian margin cores. Thus, despite the available data, further studies are needed to finally unravel cause and effects of palaeoenvironmental changes in the Skagerrak region through the last two millennia.

\section{Acknowledgements}

This work has been supported by the European Union through funding of the project HOLSMEER-Late Holocene Shallow Marine Environments of Europe (EVK2-CT-2000-00060). We are grateful to the Institut Paul-Emil Victor (IPEV) for IMAGES coring operation onboard the R/V Marion Dufresne. This paper benefited greatly from the reviews by Christian Hass and Kay-Christian Emeis.

\section{References}

Abrantes, F. 1988: Diatom productivity peak and increased circulation during latest Quaternary: Alboran basin (Western Mediterranean). Marine Micropaleontology 13, 79-96.

Alve, E. and Murray, J. 1995: Benthic foraminiferal distribution and abundance changes in Skagerrak surface sediments: 1937 (Höglund) and 1992/93 data compared. Marine Micropaleontology $25,269-88$.

1997: High benthic fertility and taxonomy of foraminifera: a case study of the Skagerrak, North Sea. Marine Micropaleontology 31, 157-75.

Andersson, C., Risebrobakken, B., Jansen, E. and Dahl, S.O. 2003: Late Holocene surface ocean conditions of the Norwegian Sea (Vøring Plateau). Paleoceanography 18, 1044, doi:10.1029/ 2001PA000654.

Battarbee, R.W. 1973: A new method for estimation of absolute microfossil numbers with reference especially to diatoms. Limnology and Oceanography 18, 647-52.

Bergsten, H., Nordberg, K. and Malmgren, B. 1996: Recent benthic foraminifera as tracers of water masses along a transect in the Skagerrak, north-eastern North Sea. Journal of Sea Research 35, $111-21$.

Björck, S. and Clemmensen, L.B. 2004: Aeolian sediment in raised bog deposits, Halland, SW Sweden: a new proxy record of Holocene winter storminess variation in southern Scandinavia? The Holocene 14, 677-88.

Briffa, K.R., Jones, P.D., Bartholin, T.S., Eckstien, D., Schweingruber, F.H., Karlen, F.H., Zetterberg, P. and Eronen, M. 1992: Fennoscandian summers from AD 500: temperature changes on short and long timescales. Climate Dynamics 7, 111-19.

Conradsen, K. and Heier-Nielsen, S. 1995: Holocene paleoceanography and paleoenvironments of the SkagerrakKattegat, Scandinavia. Paleoceanography 10, 801-13.

Conradsen, K., Bergsten, H., Knudsen, K.L., Nordberg, K. and Seidenkrantz, M.-S. 1994: Recent benthic foraminiferal distribution in the Kattegat and the Skagerrak, Scandinavia. Cushman Foundation Special Publication 32, 53-68.

Dahl, F.E. 1978: On the existence of a deep countercurrent to the Norwegian Coastal Current in the Skagerrak. Tellus 30, 552-56.

Danielssen, D.S., Davidsson, L., Edler, L., Fogelquist, E., Fonselius, S.H., Føyn, L., Hernroth, I., Håkansson, B., Olsson, I. and Svendsen, E. 1991: SKAGEX: some preliminary results. International Council for the Exploitation of the Sea CM 1991, $\mathrm{C}: 2,14 \mathrm{pp}$.

Dooley, H.D. and Furnes, G.K. 1981: Influence of the wind field on the transport of the northern North Sea. In Saetre, R. and Mork, 
M., editors, The Norwegian coastal current. University of Bergen 1, $57-71$.

Eiríksson, J., Bartels-Jónsdóttir, H.B., Cage, A.G., Gudmundsdóttir, E.R., Klitgaard-Kristensen, D., Marret, F., Rodrigues, T., Abrantes, F., Austin, W.E.N., Jiang, H., Knudsen, K.-L. and Sejrup, H.-P. 2006: Variability of the North Atlantic Current during the last 2000 years based on shelf bottom water and sea surface temperatures along an open ocean/shallow marine transect in western Europe. The Holocene 16, 1017-29 (this issue). Eisma, D. and Kalf, J. 1987: Dispersal, concentration and deposition of suspended matter in the North Sea. Journal of the Geological Society 144, 161-78.

Emeis, K.-C., Struck, U., Blanz, T., Kohly, A. and Voss, M. 2003 Salinity changes in the central Baltic Sea (NW Europe) over the last 10000 years. The Holocene 13, 411-21.

Fenner, J. 1981: Diatoms in the Eocene and Oligocene sediments off NW Africa. Their stratigraphic and paleoceanographic occurrences. PhD Thesis, University of Kiel 230 pp.

Grove, J.M. 2002: Climatic Change in Northern Europe over the last two thousand years and its possible influence on human activity. In Wefer, G., Berger, W.H., Behre, K.-E. and Jansen, E., editors, Climate development and history of the North Atlantic realm. Springer, 313-26.

Gyllencreutz, R. 2005: Late Glacial and Holocene paleoceanography in the Skagerrak from high-resolution grain size records. Palaeogeography, Palaeoclimatology, Palaeoecology 222, 344-69.

Gyllencreutz, R. and Kissel, C. 2006: Late Glacial and Holocene paleoceanographic variability in north-eastern Skagerrak interpreted from grain size and magnetic properties in IMAGES core MD99-2286. Quaternary Science Reviews 25, 1247-63.

Gyllencreutz, R., Jakobsson, M. and Backman, J. 2005: Holocene sedimentation in the Skagerrak interpreted from chirp sonar and core data. Journal of Quaternary Science 20, 21-32.

Hass, H.C. 1993: Depositional processes under changing climate: upper Subatlantic granulometric records from the Skagerrak (NENorth Sea). Marine Geology 111, 361-78.

- 1996: Northern Europe climate variations during late Holocene: evidence from marine Skagerrak. Palaeogeography, Palaeoclimatology, Palaeoecology 123, 121-45.

Hebbeln, D., Scheurle, C. and Lamy, F. 2003: Depositional history of the Helgoland Mud Area, German Bight, North Sea. GeoMarine Letters 23, 81-90.

Heier-Nielsen, S., Heinemeier, J., Nielsen, H.L. and Rud, N. 1995: Recent reservoir ages for Danish fjords and marine waters. Radiocarbon 37, 875-82.

Hughen, K.A., Baillie, M.G.L., Bard, E., Bayliss, A., Beck, J.W., Bertrand, C., Blackwell, P.G., Buck, C.E., Burr, G., Cutler, K.B., Damon, P.E., Edwards, R.L., Fairbanks, R.G., Friedrich, M., Guilderson, T.P., Kromer, B., McCormac, F.G., Manning, S., Bronk Ramsey, C., Reimer, P.J., Reimer, R.W., Remmele, S., Southon, J.R., Stuiver, M., Talamo, S., Taylor, F.W., van der Plicht, J. and Weyhenmeyer, C.E. 2004: Marine04 marine radiocarbon age calibration, $0-26$ cal kyr BP. Radiocarbon 46, 1059-86

Hughes, M.K. and Diaz, H.F. 1994. Was there a 'Mediaeval Warm Period', and if so, where and when? Climatic Change 26, 109-42. Huntley, B., Bailie, M., Grove, J.M., Hammer, C.U., Harrison, S.P., Jacomet, S., Jansen, E., Karlén, W., Koc, N., Luterbacher, J., Negendank, J. and Schibler, J. 2002. Holocene paleoenvironmental changes in north-west Europe: climatic implications and the human dimension. In Wefer, G., Berger, W.H., Behre, K.-E. and Jansen, E., editors, Climate development and history of the North Atlantic realm. Springer, 259-98.

Hurrell, J. 1995: Decadal trends in the North Atlantic Oscillation: regional temperatures and precipitation. Science 269, 676-79.

Imbrie, J., Hays, J.D., Martinson, D.G., McIntyre, A., Mix, A.C., Morley, J.J., Pisias, N.G., Prell, W.L. and Shackleton, N.J. 1984: The orbital theory of Pleistocene climate: support from a revised chronology of the marine $\delta^{18} \mathrm{O}$ record. In Berger, A.L., Imbrie, J., Hays, J.D., Kukla, G. and Saltzman, B., editors, Milankovitch and climate. Part 1. D. Reidel, 269-305.
Jansen, J.H.F., van der Gaast, S.J., Koster, B. and Vaars, A.J. 1998: CORTEX, a shipboard XRF-scanner for element analyses in split sediment cores. Marine Geology 151, 143-53.

Jennerjahn, T.C., Ittekkot, V., Arz, H.W., Behling, H., Pätzold, J. and Wefer, G. 2004: Asynchronous terrestrial and marine signals of climate change during Heinrich events. Science 306, 2236-39.

Jiang, H. 1996: Diatoms from the surface sediments of the Skagerrak and the Kattegat and their relationship to spatial changes of environmental variables. Journal of Biogeography 23, 129-37.

Johannesen, T., Jansen, E., Flatøy, A. and Ravelo, A.C. 1994: The relationship between surface water masses, oceanographic fronts and paleoclimatic proxies in surface sediments of the Greenland, Iceland and Norwegian Seas. In Zahn, R. and Kaminski, M., editors, Carbon cycling in the glacial ocean. NATO ASI Series I, 17. Springer, 61-85.

Jones, P.D. and Mann, M.E. 2004: Climate over past millennia. Reviews of Geophysics 42, doi:10.1029/2003RG000143.

Jones, P.D., Osborn, T.J. and Briffa, KR. 2001: The evolution of climate over the last millennium. Science 292, 662-67.

Klitgaard-Kristensen, D., Sejrup, H.P. and Haflidason, H. 2001: The last $18 \mathrm{kyr}$ fluctuations in Norwegian Sea surface conditions and implications for the magnitude of climatic change: evidence from the North Sea. Paleoceanography 16, 455-67.

Klitgaard-Kristensen, D., Sejrup, H.P., Haflidason, H. and Berstad, I.M. 2004: Eight-hundred-year temperature variability from the Norwegian continental margin and the North Atlantic thermohaline circulation. Paleoceanography 19, PA2007, doi:10.1029/2003PA000960.

Knudsen, K.L., Conradsen, K., Heier-Nielsen, S. and Seidenkrantz, M.-S. 1996: Paleoenvironments in the Skagerrak-Kattegat basin in the eastern North Sea during the last deglaciation. Boreas 25, $65-77$.

Koç, N. and Jansen, E. 2002: Holocene evolution of the North Atlantic ocean and the Nordic Seas-a synthesis of new results. In Wefer, G., Berger, W.H., Behre, K.-E. and Jansen, E., editors, Climate development and history of the North Atlantic realm. Springer, 165-73.

Kuhlmann, H., Meggers, H., Freudenthal, T. and Wefer, G. 2004: The transition of the monsoonal and $\mathrm{N}$ Atlantic climate system off NW Africa during the Holocene. Geophysical Research Letters 31, 22, L22204.

Lamb, H.H. 1977: Climate: present, past and future, volume 2 : Climatic history and the future. Methuen \& Co Ltd, 1-853.

- 1979: Climatic variation and changes in the wind and ocean circulation: the Little Ice Age in the Northeast Atlantic. Quaternary Research 11, 1-20.

Ljøen, R. and Svansson, A. 1972: Long-term variations of subsurface temperatures in the Skagerrak. Deep-Sea Research 19, $277-88$.

Lohse, L., Malschaert, J.F.P., Slomp, C.P., Helder, W. and van Raaphorst, W. 1995: Sediment-water fluxes of inorganic nitrogen compounds along the transport route of organic matter in the North Sea. Ophelia 41, 173-97.

Longva, O. and Thorsnes, T., editors 1997: Skagerrak in the past and at the present - an integrated study of geology, chemistry, hydrography and microfossil ecology. Geological Survey of Norway, Special Publication 8, 1-100.

Marshall, J., Kushnir, Y., Battisti, D., Chang, P., Czaja, A. Dickson, R., Hurrell, J., McCartney, M., Saravanan, R. and Visbeck, M. 2001: North Atlantic climate variability: phenomena, impacts and mechanisms. International Journal of Climatology 21, 1863-98.

McCave, I.N., Manighetti, B. and Robinson, S.G. 1995: Sortable silt and fine sediment size/composition slicing: parameters for paleocurrent speed and paleoceanography. Paleoceanography 10 , 593-610.

Meldgaard, S. and Knudsen, K.L. 1979: Metoder til indsamling og oparbejdnung af prøver til foraminifer-analyser. Dansk Natur Dansk Skole Arsskrift 1979, 48-57.

Murray, J. 1991: Ecology and paleoecology of benthic foraminifera. Longman Scientific \& Technical, 397 pp. 
Nadeau, M.J., Schleicher, M., Grootes, P.M., Erlenkeuser, H., Gottolong, A., Mous, D.J.W., Sarnthein, J.M. and Willkomm, N. 1997: The Leibniz-Labor AMS facility at the Christian-Albrechts University, Kiel, Germany. Nuclear Instruments and Methods in Physics Research 123, 22-30.

Nordberg, K. 1991: Oceanography in the Kattegat and Skagerrak over the past 8000 years. Paleoceanography 6, 461-84.

Qvale, G. and van Weering, T.C.E. 1985: Relationship of surface sediments and benthic foraminiferal distribution patterns in the Norwegian Channel (Northern North Sea). Marine Micropaleontology 9, 469-88.

Rasmussen, B. and Gustafsson, B.G. 2003: Computation of nutrient pools and fluxes at the entrance to the Baltic Sea, 1974-1999. Continental Shelf Research 23, 483-500.

Rochon, A., de Vernal, A., Turon, J.L., Matthiessen, J. and Head, M.J. 1999: Distribution of dinoflagellate cyst assemblages in surface sediments from the North Atlantic Ocean and adjacent basins and quantitative reconstruction of sea-surface parameters. Special Contribution Series, American Association of Stratigraphic Palynologists 35.

Rodhe, J. 1987: The large-scale circulation in the Skagerrak; interpretation of some observations. Tellus 39A, 245-53.

1996: On the dynamics of the large-scale circulation of the Skagerrak. Journal of Sea Research 35, 9-21.

1998: The Baltic and North Seas: a process-oriented review of the physical oceanography. In Robinson, A.R. and Brink, H.H., editors, The sea. John Wiley \& Sons, 699-732.

Röhl, U., Bralower, T.J., Norris, R.D. and Wefer, G. 2000: New chronology for the late Paleocene thermal maximum and its environmental implications. Geology 28, 927-30.
Scheurle, C. 2004: Climate development and its effect on the North Sea environment during the Late Holocene. $\mathrm{PhD}$ Thesis, University of Bremen, $121 \mathrm{pp}$.

Scheurle, C. and Hebbeln, D. 2003: Stable oxygen isotopes as recorders of salinity and river discharge in the German Bight, North Sea. Geo-Marine Letters 23, 130-36.

Scheurle, C., Hebbeln, D. and Jones, P. 2005: An 800 year record of salinity and river discharge in the German Bight. The Holocene 15, 429-34.

Schrader, H.J. and Gersonde, R. 1978: Diatoms and silicoflagellates. Utrecht Micropaleontological Bulletin 17, 129-76. Seidenkrantz, M.-S. 1993: Subrecent changes in the foraminiferal distribution in the Kattegat and the Skagerrak, Scandinavia: anthropogenic influence and natural causes. Boreas 22, 383-95.

Stabell, B. and Thiede, J. 1985: Upper Quaternary marine Skagerrak (NE North Sea) deposits: stratigraphy and depositional evnironment. Norsk Geologisk Tidsskrift 65, 9-149. Stuiver, M., Reimer, P.J., Bard, E., Beck, J.W., Burr, G.S., Hughen, K.A., Kromer, B., McCormac, F.G., v.d. Plicht, J. and Spurk, M. 1998: INTCAL98 radiocarbon age calibration, 24000-0 cal BP. Radiocarbon 40, 1041-83.

van Weering, T.C.E., Berger, G.W. and Kalf, J. 1987: Recent sediment accumulation in the Skagerrak, northeastern North Sea. Netherlands Journal of Sea Research 21, 177-89.

van Weering, T.C.E., Rumohr, J. and Liebezeit, G. 1993: Holocene sedimentation in the Skagerrak: a review. Marine Geology 111, 379-91.

von Haugwitz, W., Wong, H.K. and Salge, U. 1988: The mud area southeast of Helgoland: a reflection seismic study. Mitteilungen Geologisch-Paläontologisches Institut Universität Hamburg 65, 409-22. 